\title{
Impact of Investments in Special Economic Zones on Regional Development: The Case of Poland
}

\begin{abstract}
Special economic zones in Poland (SEZs) were established to explicitly enhance regional development, crafting a series of investment incentives designed to boost investment attractiveness in particular regions. How have these incentives fared in reality? To capture the impact of SEZs upon regional development in the country, we use a counterfactual evaluation method across a number of important metrics, including company investment, number of companies, and unemployment. Our analysis shows that SEZs have had a strongly positive impact upon the development of the least-developed regions in Poland, while in relatively richer ones the effect was weak or even negative.
\end{abstract}

Key words: special economic zones, regional development, investment, unemployment rate, Poland

JEL: R11, R12, R38, R53

\section{INTRODUCTION}

In 1994, with an eye on encouraging investment, fourteen special economic zones (SEZs) were established in the least-developed regions in Poland. As stipulated in the Act on Special Economic Zones (1994), the goal of these SEZs was to enhance social and economic development and the competitiveness of regions affected by industrial restructuring at the beginning of political and economic transformations of the 1990s. In particular, the zones were designed to develop new technologies, create new jobs, develop exports, and utilize and improve existing infrastructure in the "uninhabited" area of a particular region. In pursuit of these lofty goals, potential investors were offered special state aid and income tax allowances to lure them into these new zones. Representing the major economic policy instrument dedicated to regional development, 
SEZs have remained the cornerstone of regional economic policy in Poland over the past 20 years.

The primary aim of this paper is to evaluate the effectiveness of these SEZs in meeting their objectives across the metrics specified in the original legislation. Utilizing the framework of New Economic Geography (NEG) theory and in particular ideas on economic agglomeration, one would expect to see SEZs encouraging the growth of existing businesses and the emergence of start-ups in regions of Poland with SEZs, as well as an inflow of investors to these territories. Furthermore, greater involvement of manufacturing and service businesses in regions with SEZs, harmed in the transition to a market economy, should increase the demand for labour and, consequently, stimulate local labour markets. Much as the framers of the Act hoped, we would anticipate the total effect of special economic zones in Poland to improve the social and economic development of the regions they were based in (Diagram 1).

Diagram 1. SEZs impact mechanism.

(file: Diagram 1. SEZs impact mechanism.tiff)

Using a counterfactual evaluation method, our results show that SEZs have been effective in some ways in achieving their goals, but in a manner likely unanticipated in 1994. While SEZs appear to have increased jobs available in a particular region and increased the gross value-added of specific firms, new firm entry has been indistinguishable in regions with SEZs from those without. It appears that, rather than creating broad-based regional development, Poland's SEZs have benefited a small number of larger firms. 
The rest of the paper is organised as follows: in the next section, we discuss the theoretical basis to analyse agglomeration effects of SEZs in Poland. In the third section, we examine the theoretical basis and anticipated effects of SEZs, based on prior research. Section four describes our research methodology and data, while the fifth section discusses the empirical results. The final section offers some concluding thoughts.

\section{SEZS IN POLAND: STYLISED FACTS}

As noted above, the overarching goal of the state aid administered via SEZs in Poland was to address a geographic imbalance in investment distribution across the country, boosting the then-low investment attractiveness of the poorest areas of Poland (Ambroziak, 2009). As with SEZs around the world, the model chosen by Poland was distinctly different from export processing zones (EPZs), a policy tool in countries which shifted from import-substitution policies to export-led growth policies and which was specialised mainly in manufacturing for export. While EPZs provided a package of financial incentives, streamlined business administration, free trade advantages, and a liberal regulatory environment solely to exporters (World Bank, 1992:7, Engman et al., 2007:5), SEZs offered similar incentives but to all industries. Rather than focusing on outward-orientation (exports), the SEZ model attempts to solicit inward investment, enhancing the competitiveness of manufacturing industries and service providers through agglomeration benefits, concentrating industries in one geographical area. In practice, as done in Poland, SEZ locations are often restricted to relatively remote areas to act as growth poles for regional development (World Bank, 2008:12); in this manner, SEZs would change incentives at the margin, encouraging entrepreneurs to undertake economic activity which would not have existed in the absence of such aid. For the 
poorest regions of a country, SEZs could be expected to overcome barriers common to underdeveloped areas, including poor infrastructure and unskilled labour.

Poland's SEZ model was structured to accommodate the process of EU accession, which the country officially began in February 1994 (the Association Agreement was signed in 1991 but came into force three years later). As written in the 1994 Act, Polish SEZs were compliant with EU rules for state aid admissibility in cases of “market imperfection” (European Commission, 2005), as special EU guidelines on regional state aid allowed for granting public subsidies to companies to promote the expansion and diversification of economic activities pursued in least-favoured regions (identified as those where GDP per capita is below 75\% of the EU average, European Commission, 1998, 2006).

Despite the intention of EU rules to allow state aid for specifically-designated and disadvantaged regions within a country, Poland's interpretation was more expansive. Poland, as one of the least developed Member States, appeared to have carte blance to provide regional state aid (also within the framework of SEZs) to businesses based on its territory, with only variety in intensity ceilings. This view meant that that SEZs were not only targeted at the country's poorest regions, but instead expanded and fragmented across the entire country. What transpired was, guided by the suggestions of potential investors, the government adopted a rather flexible stance towards the boundaries of SEZs, showing a readiness to adapt them to investor needs rather than as part of a regional development strategy.

This approach necessarily subverted the original aim of the SEZ: in particular, entrepreneurs, especially foreign ones, had been seeking to locate their investment projects in Poland close to their competitors and/or transport infrastructure, meaning they had an incentive to choose better-developed areas and disregard regions lagging 
behind (Cieślik, 2005, Laskowski, 2013, Nazarczuk, 2013). As part of an overall strategy to encourage investment, the government also excluded regions least-prepared for investment as candidates for SEZs, replacing them with better-developed ones (Ordinance, 2008, Ambroziak, 2009). As a result, by the end of 2013, SEZs could be found in 151 cities and 217 gminas (NUTS V administrative unit in Poland) hosting “subzones” of fourteen SEZs (Ministerstwo Gospodarki, 2014).

\section{ANTICIPATED EFFECTS OF POLAND'S SEZS}

The effects of the Polish approach to SEZs may be analysed in the light of the agglomeration process predicted in New Economic Geography (NEG) theory. As noted by Krugman (1990), one of the fundamental assumptions of NEG is that a myriad of factors (increasing returns to scale due to new knowledge spill-over effects, demand generated by the domestic market, or costs of trade in the context of Weber's theory (Weber, 1929) on location of industries based on the 'least cost principle’ and a role of transportation costs can explain the agglomeration (concentration) of industry in betterdeveloped regions of a country (Krugman, 1991; Venables, 2006). Of these factors, increasing returns to scale may be the most important in generating agglomerations of economic activity in a region where capital and labour are abundant (Fujita et al., 1999). Incitement to agglomerate may also come from other aspects of the business environment beyond mere factor endowments, including improved technical conditions and the emerging prospect of collaboration with other entrepreneurs, universities and research centres (Rosenthal and Strange, 2001). Improved governance in the form of local authorities may also play a role (Dziemianowicz, 2008, Lizińska, Marks-Bielska and Kisiel, 2011). 
Given the tendency towards agglomeration and the stylised facts surrounding Poland's experiences with SEZs, we may then formulate three separate hypotheses regarding the effects of SEZs in Poland:

- H1: the inflow of capital into a SEZ in a given region of Poland should be accompanied by the interest of other investors, which results in an increase of gross value of fixed assets per company in a given region;

As noted above, the Polish approach to the establishment of SEZs was to place them in more developed regions, near relatively better developed industrial-serviceresearch centres, close to already existing companies and along well-advanced transportation routes (Ambroziak, 2009). Given this reality, we would expect to see companies which did locate in the SEZs to fare rather well compared to those outside the SEZs, as they would be advantaged by tax allowances and breaks in addition to existing advantages.

- H2: the inflow of capital into a SEZ in a given region would be accompanied by an overall increase in the number of business entities (co-operators, suppliers and business customers at a regional level);

- H3: investment inflow into a SEZ increases the number of new jobs and therefore reduces the unemployment rate in a given region.

These final two hypotheses build on agglomeration theory to suggest that Poland's SEZs would not only attract new entrants to the zones but also benefit existing firms. Moreover, economic activity and investment into regions with SEZs should have 
increased, building on the natural advantages of the selected regions and the incentives offered by the government.

A common problem of lagging regions is their inability to utilize factors already present on their territory. The establishment of a SEZ in a given region and the arrival of new investors with new technologies and new production processes should theoretically lead to gains, as previously unused factors available in the region are brought on-line. In such a scenario, there should be a boom of local and incoming entrepreneurship, the creation of inter-business linkages between local and new companies, and, consequently, the reduction of unemployment through the creation of new and better jobs. It is expected that all of the aforementioned processes launched by market mechanisms can be strengthened by public intervention in the form of (inter alia) establishment of SEZs. However, it should be underlined that each public intervention can also have many negative consequences for competition (Ambroziak, 2015a). Nevertheless, we expect an increase in number of economic entities and a decrease in unemployment rate in poviats with SEZs.

\section{RESEARCH METHODOLOGY}

In order to test our three hypotheses, our examination will apply a counterfactual impact evaluation of economic and social consequences of all the subzones of the fourteen SEZs on regional development. A fundamental problem with causal inference is the impossibility to observe one and the same object in two situations: i.e. with and without the intervention (Holland, 1986: 945). To address this issue and to ensure methodological rigour, our approach to understanding the effect of SEZs in Poland will compare what actually happened in the subzones in question with what would have 
happened in the absence of an SEZ (White, 2006:3) across several metrics, including gross value of fixed assets per company, the number of entrepreneurs in a region, and unemployment rates. To construct the counterfactual, we needed to identify a 'perfect clone' for each region and beneficiary of the intervention (i.e. of the SEZ). However, due to the fact that no perfect clone exists for a single individual region, two groups had to be identified: beneficiaries and non-beneficiaries of intervention, identical in all pertinent aspects except for the treatment effect of the intervention. Consequently, only the intervention could explain any differences in outcomes between the two groups once the intervention has been introduced (Baker, 2000:1, Gertler et al. 2011:37). Differences observed in changes in gross value of fixed assets per company, the number of entrepreneurs, and unemployment rates in the experimental group (poviats with SEZs) compared to the changes in the control group (poviats without SEZs) in the period of 2005-2013 were interpreted as SEZ impact on regional development

For our analysis, we established an experimental (treatment) group composed of all regions with SEZs and a control (comparison) group of the rest of regions in Poland without any SEZs. However, an issue encountered in previous studies is that they often showed effects of economic activities in SEZs broken down by the fourteen SEZs (identified with names of fourteen state-owned companies responsible for administering SEZs in Poland) (Dziemianowicz, Hausner and Szlachta 2000, Kryńska 2000, Domański and Gwosdz 2005, Kozaczka, 2007, 2008, Pastusiak, 2011, Laskowski 2013, Siudak 2013, Typa 2013, Hajduga, 2014). Due to the above-mentioned frequent changes in SEZs borders introduced by the government in response to potential investors' requests, SEZs are heavily fragmented. Thus, in Poland, the names of the state-owned companies which manage SEZs do not necessarily overlap with geographic 
names of the real locations of SEZ subzones and, consequently, some conclusions on the impact of SEZs upon regions can be misinterpreted.

In order to overcome this problem, it is preferable to observe changes in economic activity at the level of poviats, one of the tiers of territorial statistics, equivalent of NUTS 4, which remains in the middle of NUTS classification. On the one hand, previous work suggests that companies in SEZs attracted workers and suppliers from gminas (territorial units at the lowest tier of administrative structure in Poland NUTS 5) and poviats, in which they are based or from neighbouring areas (Ambroziak, 2009). On the other hand, other studies have captured the impact of SEZs upon social and economic development of bigger regions, such as voivodeships (NUTS 2) (Ambroziak, 2015b).

With the territorial boundaries established, the next step is to select poviats for the experimental and control groups which are statistically equivalent, i.e.: a) identically respond to intervention; b) be identically influenced by other external factors and interventions; and c) be identical when it comes to their characteristics in terms of important demographic and economic data. Due to the fact that all central government tools apply to all poviats across the board, the only differences in their responses to the presence of an SEZ and thus in their socio-economic performance may result from (i) being part of a particular voivodeship (which determines admissible regional state aid available in, inter alia, SEZs); and (ii) unequal advancement of regional development. In both cases we are speaking of factors relevant for the interest of business operators in investing in a given area, including in an SEZ. In order to eliminate differences between the experimental and control groups of poviats caused by differences in external factors that influence their investment attractiveness, we distinguished subgroups according to the allowable ceilings of regional aid intensity. These ceilings, applicable to investment 
aid offered in SEZs, are exogenous, as they depend on the level of development of a particular voivodeship, in which a given poviat is located (the highest aid ceilings are available in the least-developed voivodeships). Therefore, on the basis of the regional state aid map for Poland, we take into account relative regional development level in voivodeship (NUTS 2) where a given poviat is located. Then, we applied the 3-point regional development scale according to GDP per capita in relation to the EU average in 2005: a) $\leq 45 \%$, b) $45 \%<$ and $\leq 60 \%$, c) $60 \%<$ and $\leq 75 \%$ (as developed by the European Commission for the Regional Aid Map, Guideline 2006).

Moreover, to ensure that the examined groups of poviats identically respond to the inflow of investments to SEZs and are identical in terms of socio-economic growth, we distinguished subgroups of poviats, taking into account their relative regional development (since GDP data for NUTS 4 - poviats - were not available, we used data for NUTS 3 - sub-regions- treating them as approximate to the real-life situation in poviats). Then we applied the 3-point regional development scale according to GDP per capita in relation to the EU average in 2005 : a) $\leq 45 \%$, b) $45 \%<$ and $\leq 60 \%$, c) $60 \%<$ and $\leq 75 \%$.

The aforementioned distinctions and classifications were not sufficient to evaluate the real impact of SEZs upon the development of poviats because the effects of SEZs may also depend on the intensity of investment into SEZs. Hence, the classification of poviats in the experimental (treatment) group was expanded by using the value of investment in SEZs compared to the gross value of fixed assets in individual poviats. Taking this indicator into account, we continued disaggregation and identified three subgroups within the experimental (treatment) group of poviats, where SEZs investment intensity ranged, respectively: a) $\leq 5 \%$, b) $5 \%<$ and $\leq 20 \%$, c) $>20 \%$. 
Finally, on the basis of these divisions, for each group (experimental and control) we identified seven categories of poviats in Poland (Table 1).

Table 1. Categories of poviats, depending on regional development level of voivodeships in which they are located.

\begin{tabular}{|c|c|c|c|c|c|c|c|}
\hline \multirow{3}{*}{$\begin{array}{l}\text { Voivodeships } \\
\text { GDP per capita } \\
\text { in relation to } \\
\text { the EU average }\end{array}$} & \multirow{3}{*}{$\begin{array}{l}\text { Poviats } \\
\text { GDP per capita in } \\
\text { relation to the EU } \\
\text { average }\end{array}$} & \multirow{3}{*}{$\begin{array}{l}\text { Control } \\
\text { group }\end{array}$} & \multicolumn{4}{|c|}{ Treatment group } & \multirow{3}{*}{ Total } \\
\hline & & & \multirow{2}{*}{ Subtotal } & \multicolumn{3}{|c|}{$\begin{array}{l}\text { Poviats whose share of SEZs investments } \\
\text { in gross value of fixed assets ranged }\end{array}$} & \\
\hline & & & & $\leq 5 \%$ & $\begin{array}{l}5 \%<\text { and } \\
\leq 20 \%\end{array}$ & $>20 \%$ & \\
\hline \multirow{2}{*}{ 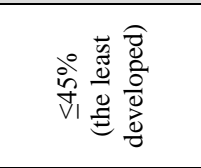 } & $\begin{array}{c}\leq 45 \% \\
\text { the least developed } \\
\text { (the poorest) }\end{array}$ & 85 & 106 & 65 & 27 & 14 & 191 \\
\hline & $\begin{array}{c}45 \%<\text { and } \leq 60 \% \\
\text { (less developed) }\end{array}$ & 2 & 3 & 1 & 1 & 1 & 5 \\
\hline \multirow{3}{*}{ 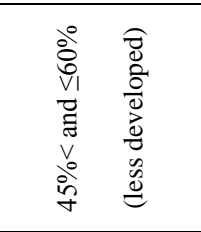 } & $\begin{array}{c}\leq 45 \% \\
\text { the least developed } \\
\text { (the poorest) }\end{array}$ & 41 & 56 & 25 & 19 & 12 & 97 \\
\hline & $\begin{array}{c}45 \%<\text { and } \leq 60 \% \\
\text { (less developed) }\end{array}$ & 9 & 19 & 9 & 6 & 4 & 28 \\
\hline & $\begin{array}{l}60 \%<\text { and } \leq 75 \% \\
\text { (more developed) }\end{array}$ & 6 & 9 & 7 & 1 & 1 & 15 \\
\hline \multirow{2}{*}{ 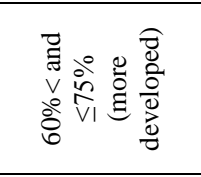 } & $\begin{array}{c}\leq 45 \% \\
\text { the least developed } \\
\text { (the poorest) }\end{array}$ & 15 & 10 & 5 & 5 & 0 & 25 \\
\hline & $\begin{array}{c}45 \%<\text { and } \leq 60 \% \\
\text { (less developed) }\end{array}$ & 7 & 8 & 6 & 1 & 1 & 15 \\
\hline \multicolumn{2}{|c|}{ Total (category of all-poviats) } & 165 & 211 & 118 & 60 & 33 & 376 \\
\hline
\end{tabular}

Source: own calculations.

Our study covers the entire population of poviats in Poland, giving us 376 territorial units in our sample ${ }^{\mathrm{i}}$. By selecting the treatment and control groups of regions, we divided poviats first into two categories composed, respectively, of 211 and 165 units of territorial statistics. Secondly, they were divided into seven proposed socioeconomic categories, which reduced the membership (population) of respective subgroups. Thirdly, by additionally considering the investment intensity of SEZs we managed, on one hand, to estimate the impact of this indicator upon our various metrics. To this end, we analysed investments in SEZs average intensity measured by the share of the total (cumulated) value of investments in SEZs at the end of a given year in gross value of fixed assets in companies, in selected categories of poviats in the period 2005- 
2013 (Table 2). This period also allowed us to examine not only investments in zones after Poland's EU accession but also earlier projects dating back to the beginnings of the SEZs.

As Table 2 shows, the intensity of investments in SEZs relative to Gross Value of Fixed Assets in a given region was the highest in the least and less-developed poviats situated in the least and less-developed voivodeships. Simultaneously, the moredeveloped poviats from both less- and better-developed voivodeships see a much lower share of SEZs investments in GVFA. This effect is separate from the larger absolute values of SEZs investments in the poorer parts of Poland, where state aid ceilings were relatively higher, but appears to be instead a result of much lower original total investments in poorer regions (i.e. a convergence effect). Taking this into account, we can expect that higher SEZ investment intensity, recorded in the lagging regions with the highest admissible state aid ceilings, correlated with greater expected impacts on value added and also on overall regional development.

Table 2. The differences in changes of certain indicators between categories of poviats with and without SEZs in the period of 2005-2013.

\begin{tabular}{|c|c|c|}
\hline $\begin{array}{l}\text { Voivodeships } \\
\text { GDP per capita in relation } \\
\text { to the EU average }\end{array}$ & $\begin{array}{l}\text { Poviats } \\
\text { GDP per capita in relation to the EU average }\end{array}$ & $\begin{array}{l}\text { Share of investments in SEZs in the total } \\
\text { gross value of fixed assets (\%) }\end{array}$ \\
\hline \multirow{2}{*}{$\leq 45 \%$} & $\leq 45 \%$ & 7.6 \\
\hline & $45 \%<$ and $\leq 60 \%$ & 13.6 \\
\hline \multirow{3}{*}{$45 \%<$ and $\leq 60 \%$} & $\leq 45 \%$ & 12.5 \\
\hline & $45 \%<$ and $\leq 60 \%$ & 9.4 \\
\hline & $60 \%<$ and $\leq 75 \%$ & 4.6 \\
\hline \multirow{2}{*}{$60 \%<$ and $\leq 75 \%$} & $\leq 45 \%$ & 5.9 \\
\hline & $45 \%<$ and $\leq 60 \%$ & 5.3 \\
\hline
\end{tabular}

Explanatory notes:

Source: Own calculations. 
The actual analysis of the impact of SEZs on regional development was carried out using a double difference (difference-in-difference) method of evaluation for each region, deducting the difference in the outcome before and after the intervention in the control group from the same difference in the experimental group. In this manner, we are able to approximate the impact of the SEZ across the metrics of interest (European Commission 2014, Gertler et al. 2011, pp. 95-96).

The benefits of the counterfactual method are legion for an examination such as this. In the first instance, this approach has previously been adopted by researchers as an accepted component of many evaluation programs concerning public interventions, including those run by the government (Heckman and Hotz, 1989:862, Trzciński, 2009:11-12). For our purposes, the method allows for the assignment of outcomes, effects, and consequences of SEZs and, by the same token, verify the accomplishment of goals assumed for SEZs in Poland (on which our three detailed hypotheses are based).

The method also has the benefit of avoiding an issue which plagued earlier research, mainly a focus on absolute effects of investment in SEZs in terms of capital inflow and job creation in zones and not the impact of SEZs per se. Indeed, some of the outcomes studied in the earlier work reflect overall economic and social changes, including those caused by factors other than SEZs, rather than focusing on direct effects of the zones (PriceWaterhouseCoopers, 2008, Ernst and Young 2011, Pastusiak, 2011, KPMG 2012, Siudak and Wątorek, 2013, Typa, 2013, Hajduga, 2014). The counterfactual method ignores (a) the effects of external factors, which affect regions covered by the research; and (b) characteristics which are irrelevant or for which it is difficult to make statistical observations. 


\section{Data}

Data concerning the investment stock in SEZs comes from Polish entrepreneurs who are obliged to report their activities in zones to the Ministry of Economy (currently the Ministry of Economic Development). Data relating to selected indicators of regional development at the poviat level came from the Local Data Bank of the Central Statistical Office of Poland (GUS), including gross value of fixed assets (amounts involved in purchasing fixed assets or in manufacturing them, without deducting their consumption) per entrepreneur, the number of economic operators (including those holding SEZ permits), and the unemployment rate. Since these social and economic indicators could have been materially influenced by Poland's EU accession and radical modifications of state aid rules with respect to SEZs (Ambroziak, 2009, 2015), the study covers nine years, starting with the first full year of the EU membership, i.e. from 2005, and runs until 2013.

\section{IMPACT OF INVESTMENTS IN SEZS UPON REGIONAL DEVELOPMENT INDICES}

\section{Gross value of fixed assets per company}

As we have already mentioned, one of the measures of the impact of special economic zones upon regional development of poviats is the change in the gross value of fixed assets (GVFA) per company. In accordance New Economic Geography theory, we assume that the inflow of capital into a SEZ in a given region triggers the interest of other investors, creating an agglomeration process. In order to estimate the impact of investment in SEZs on GVFA in poviats in Poland, we compared the ratio of average GVFA per company in 2013 to that of 2005 in (a) poviats in the experimental group (with SEZs); and (b) in poviats in the control group (without SEZs). These ratios were 
further broken down by levels of regional development (calculated as GDP per capita in relation to the EU average) and, in the case of the experimental group, also by the investment intensity of SEZs in poviats. ${ }^{\text {ii }}$

In the period covered by the study, we find in general poviats which recorded significant SEZ investment intensities (above 5\% of GVFA) exhibited a statistically significant increase in the gross value of fixed assets per company (Table 3.). On the other hand, taking into account the regional development of both poviats and voivodeships in which poviats are located, we found that the differences between changes in GVFA in poviats with and without SEZs were statistically insignificant at the $5 \%$ level.

However, we need to note two additional tendencies. As could be expected, poviats where SEZ investment intensity was above 5\% of GVFA recorded a higher increase in GVFA per company while those with a very low rate of SEZ investment noted an even lower increase in GVFA per company than in poviats without SEZs. Secondly, taking into account regional domestic product per capita in relation to the EU average, the largest increases in GVFA per company in the experimental group, in comparison to the control group, was observed in all categories of poviats from the least-developed voivodeships and the poorest ones from less-developed voivodeships.

Table 3. Change in the gross value of fixed assets per company in poviats with SEZs by categories compared to poviats without SEZs in 2005-2013 (in percentage points).

\begin{tabular}{|c|c|c|c|c|c|}
\hline \multirow{2}{*}{$\begin{array}{l}\text { Voivodeships } \\
\text { GDP per capita in relation to } \\
\text { the EU average }\end{array}$} & \multirow{2}{*}{$\begin{array}{l}\text { Poviats } \\
\text { GDP per capita in relation to the } \\
\text { EU average }\end{array}$} & \multicolumn{4}{|c|}{$\begin{array}{l}\text { Poviats whose share of SEZs investments in gross } \\
\text { value of fixed assets is: }\end{array}$} \\
\hline & & Total & $<=5 \%$ & $\begin{array}{l}>5 \text { and } \\
<=20 \%\end{array}$ & $>20 \%$ \\
\hline \multirow{2}{*}{$\leq 45 \%$} & $\leq 45 \%$ & 9.64 & -9.29 & $31.30 * *$ & 6.90 \\
\hline & $45 \%<$ and $\leq 60 \%$ & 51.49 & 11.47 & -10.76 & 153.74 \\
\hline \multirow{3}{*}{$45 \%<$ and $\leq 60 \%$} & $\leq 45 \%$ & 10.53 & 2.87 & 13.15 & 15.58 \\
\hline & $45 \%<$ and $\leq 60 \%$ & -3.93 & -30.98 & 9.53 & 9.64 \\
\hline & $60 \%<$ and $\leq 75 \%$ & -5.01 & -27.4 & -2.17 & 14.54 \\
\hline \multirow{2}{*}{$60 \%<$ and $\leq 75 \%$} & $\leq 45 \%$ & -1.08 & -0.44 & -1.72 & n.a. \\
\hline & $45 \%<$ and $\leq 60 \%$ & 5.11 & -4.46 & -27.94 & 47.74 \\
\hline
\end{tabular}


Explanatory notes:

${ }^{*} \mathrm{p}<0.1, * * \mathrm{p}<0.05, * * * \mathrm{p}<0.01$. Due to large differences in numbers between certain categories of poviats, as well as small populations in certain categories, two tests were performed: both the parametric (Student's t-test) and nonparametric (Mann-Whitney U test), in order to capture statistical significance. Results of both tests have led us to the same conclusion.

The higher the positive values, the larger the positive changes with respect to the indices in poviats with SEZs in comparison to those without SEZs; while the higher the negative values, the smaller the positive changes in indices of territorial units with SEZs than in poviats without SEZs.

Source: Own calculations.

Therefore, it appears that investments in SEZs might have a positive impact on the increase in overall value of investments per capita in a region, especially in relatively poorer ones where the original investment stock was lower in comparison to better developed areas. Remaining cautious about the statistical significance of these results, they nonetheless may confirm the thesis that SEZs had an impact on the geography of capital concentration, increasing GVFA per capita in lagging regions.

Nonetheless, there is no statistically significant evidence that SEZs have led to important increases in investment stocks in regions where they were located. Firstly, positive changes in GVFA per company observed in poorer regions in comparison to richer ones may only show a dramatically lower value of capital per company in lagging areas compared to more-developed ones. Secondly, it seems that investments in SEZs in more developed areas, where existing investment stock was much higher than in poorer areas, were too low to have any impact on a change in GVFA per company. Thirdly, we should also bear in mind that some SEZ investments might be made regardless of the existence of SEZs, especially by Polish small and medium-sized companies originating from less developed regions. In those cases, SEZs did not attract new investors but only 
offered tax breaks to entrepreneurs, who would otherwise have invested in given areas. In reality, it appears that SEZs did not produce any significant and noticeable agglomeration of firms within and outside of zones in terms of GVFA per company, regardless of the regional development of regions with SEZs.

\section{The number of economic operators}

In accordance with the concept of business agglomeration proposed by NEG theory, we should expect that the inflow of capital into SEZs would be accompanied by an expansion of the business community. This assumption applies not only to new investors in SEZs but also to entrepreneurs who are external to the zones, who may consider moving to an area with a zone due to its attractive incentives. To this end, we compared the ratio of the number of economic operators in 2013 to that of 2005 in (a) poviats in the experimental group (with SEZs); and (b) poviats in the control group (without SEZs), further disaggregated by level of regional development (calculated as GDP per capita in relation to the EU average) and, in the case of the experimental group, also by the investment intensity in SEZs within the poviat.

As seen in Table 4, it appears that differences in the size of the business community between the categories of all-poviats with and without SEZs were statistically insignificant at the $10 \%$ level, with one exception, the category of allpoviats with SEZs investment intensity between 5-20\% of GVFA. In this category, we observed that poviats with SEZs reported smaller increases in the number of economic entities in comparison to those without SEZs.

Other effects can be seen in poviats with the highest intensity of investment in SEZs in relation to GVFA; those with intensities above 20\% actually had an adverse effect on the increase in the number of economic operators in comparison to poviats 
without SEZs. This same effect is observed across poviats of all levels of regional development, with only one exception (less-developed poviats from less-developed voivodeships), recording an overall lower growth rate of economic operators in poviats in the treatment group compared to the control group.

Table 4. Change in the number of economic operators in poviats with SEZs by categories compared to poviats without SEZs in the period 2005-2013 (in percentage points).

\begin{tabular}{|c|c|c|c|c|c|}
\hline \multirow{2}{*}{$\begin{array}{l}\text { Voivodeships } \\
\text { GDP per capita in relation to } \\
\text { the EU average }\end{array}$} & \multirow{2}{*}{$\begin{array}{l}\text { Poviats } \\
\text { GDP per capita in relation to the } \\
\text { EU average }\end{array}$} & \multicolumn{4}{|c|}{$\begin{array}{l}\text { Poviats whose share of SEZs investments in gross } \\
\text { value of fixed assets is: }\end{array}$} \\
\hline & & Total & $<=5 \%$ & $\begin{array}{l}>5 \text { and } \\
<=20 \%\end{array}$ & $>20 \%$ \\
\hline \multirow{2}{*}{$\leq 45 \%$} & $\leq 45 \%$ & -2.3 & 0.74 & -4.58 & -2.94 \\
\hline & $45 \%<$ and $\leq 60 \%$ & -8.9 & -28.37 & -26.81 & 28.42 \\
\hline \multirow{3}{*}{$45 \%<$ and $\leq 60 \%$} & $\leq 45 \%$ & -3.1 & -2.96 & -4.76 & -1.51 \\
\hline & $45 \%<$ and $\leq 60 \%$ & 6.3 & 9.17 & 7.06 & 2.71 \\
\hline & $60 \%<$ and $\leq 75 \%$ & -0.4 & 7.56 & -6.68 & -2.18 \\
\hline \multirow{2}{*}{$60 \%<$ and $\leq 75 \%$} & $\leq 45 \%$ & -2.7 & 3.63 & -9.11 & n.a. \\
\hline & $45 \%<$ and $\leq 60 \%$ & -2.2 & -1.99 & 6.41 & -11.15 \\
\hline \multicolumn{2}{|c|}{ All-poviats category } & -1.31 & 0.57 & $-3.94 *$ & -0.55 \\
\hline
\end{tabular}

Explanatory notes:

${ }^{*} \mathrm{p}<0.1,{ }^{* *} \mathrm{p}<0.05,{ }^{* * *} \mathrm{p}<0.01$. Due to large differences in numbers between certain categories of poviats, as well as small populations in certain categories, two tests were performed: both the parametric (Student's t-test) and nonparametric (Mann-Whitney U test), in order to capture statistical significance. Results of both tests have led us to the same conclusion.

The higher the positive values, the larger the positive changes with respect to the indices in poviats with SEZs in comparison to those without SEZs; while the higher the negative values, the smaller the positive changes in indices of territorial units with SEZs than in poviats without SEZs.

Source: Own calculations.

Given these results, we can conclude that capital inflow into SEZs did not produce a higher increase in numbers of economic entities compared to regions without SEZs. Indeed, it appears that the presence of SEZs rather discouraged entrepreneurs from locating their investments in poviats close to zones, with the exception of those 
who decided to base themselves within the SEZs. In a reversal of NEG theory, SEZs in Poland instead triggered anti-agglomeration processes in their immediate region or vicinity.

The reason behind this result can be traced to SEZ activities which may be detrimental to competition in the local market. Firms located in SEZs usually continue their business relations with co-operators and suppliers established before they started to operate in SEZs, eschewing links with new companies in favour of pre-existing ones. Thus, potential local co-operators, subcontractors and service-providers do not see an increase in business, benefits from enhanced economic activity do not increase, and thus other companies are not attracted to and operate in a given area outside SEZs. On top of these effects, new investors in SEZs, who enjoy tax breaks, are also much more competitive in terms of costs in comparison to existing local companies. This allows them to inter alia, (slightly) increase salaries, improve working conditions, and, on the basis of 'novelty and freshness effect', take over well-qualified employees from existing companies. As a result, local firms struggle with labour force scarcity, higher competitiveness of new investors from SEZs and a more favourable attitude of local authorities towards big, often foreign companies, offering new jobs. Such circumstances conspire to discourage existing and potential new companies to operate close to SEZs.

Of course, all of these phenomena also occur external to any individual operator, and so each firm interested in using an SEZ only sees maximization in terms of the short-term benefits which accrue from the zone, including legal certainty and economies of scale from being located in a given area with other companies. Therefore, there may still be agglomeration processes taking place, but there is no evidence by this metric (number of economic operators) for such an effect. 


\section{Unemployment rate}

Finally, the reduction of unemployment in the regions was one of the key reasons behind the establishment of special economic zones in Poland. Polish authorities assumed that by establishing SEZs they would attract entrepreneurs to selected areas, increase investment inflow into these same poviats, and increase the number of new jobs, mitigating social tensions on the labour market. As with the other metrics, we test whether this goal was accomplished via an assessment of changes in the unemployment rate in each poviat in 2013 compared to 2005. The comparison covered: (a) poviats in the experimental group (with SEZs); and (b) poviats in the control group (without SEZs), further disaggregated by levels of regional development (calculated as GDP per capita in relation to the EU average) and, in the case of the experimental group, also by the SEZs investment intensity in poviats.

On the basis of this examination, we can see that the unemployment rate was reduced to a higher extent in poviats with SEZs than in those without SEZs (Table 5), with strong correlations between higher SEZ investment intensity (above 5\%) and higher reductions in unemployment. Taking into account the effects of regional development, we also may see that investments in SEZs in the poorest poviats (from the least- and less-developed voivodeships) had the biggest effect on the reduction of unemployment (compared to poviats without SEZs).

Table 5. Change in the unemployment rate in poviats with SEZs by categories compared to poviats without SEZs in the period 2005-2013 (in percentage points).

\begin{tabular}{|c|c|c|c|c|c|}
\hline \multirow{2}{*}{$\begin{array}{l}\text { Voivodeships } \\
\text { GDP per capita in relation to } \\
\text { the EU average }\end{array}$} & \multirow{2}{*}{$\begin{array}{l}\text { Poviats } \\
\text { GDP per capita in relation to the } \\
\text { EU average }\end{array}$} & \multicolumn{4}{|c|}{$\begin{array}{l}\text { Poviats whose share of SEZs investments in gross } \\
\text { value of fixed assets is: }\end{array}$} \\
\hline & & Total & $<=5 \%$ & $\begin{array}{l}>5 \text { and } \\
<=20 \%\end{array}$ & $>20 \%$ \\
\hline \multirow{2}{*}{$\leq 45 \%$} & $\leq 45 \%$ & $1.66^{* * *}$ & $1.13^{* *}$ & $1.65 * * *$ & $2.20 * * *$ \\
\hline & $45 \%<$ and $\leq 60 \%$ & 0.72 & -1.85 & 0.25 & 3.75 \\
\hline $45 \%<$ and $\leq 60 \%$ & $\leq 45 \%$ & $1.51 * *$ & 0.65 & $1.56^{*}$ & $2.32 *$ \\
\hline
\end{tabular}




\begin{tabular}{|c|c|r|r|r|r|}
\hline & $45 \%<$ and $\leq 60 \%$ & 0.77 & 0.13 & 2.17 & 0.02 \\
\cline { 2 - 6 } & $60 \%<$ and $\leq 75 \%$ & 0.41 & -1.83 & 3.48 & -0.42 \\
\hline \multirow{2}{*}{$60 \%<$ and $\leq 75 \%$} & $\leq 45 \%$ & 1.83 & 1.53 & 2.13 & n.a. \\
\cline { 2 - 6 } & $45 \%<$ and $\leq 60 \%$ & 1.94 & 0.57 & 1.97 & 3.27 \\
\hline \multicolumn{2}{|l|}{ All-poviats category } & -1.31 & $1.72 * * *$ & $0.67 *$ & $1.99^{* * * *}$ \\
\hline
\end{tabular}

Explanatory notes:

${ }^{*} \mathrm{p}<0.1, * * \mathrm{p}<0.05, * * * \mathrm{p}<0.01$. Due to large differences in numbers between certain categories of poviats, as well as small populations in certain categories, two tests were performed: both the parametric (Student's t-test) and nonparametric (Mann-Whitney U test), in order to capture statistical significance. Results of both tests have led us to the same conclusion.

The higher the positive values, the larger the positive changes with respect to the indices in poviats with SEZs in comparison to those without SEZs; while the higher the negative values, the smaller the positive changes in indices of territorial units with SEZs than in poviats without SEZs.

Source: Own calculations.

These outcomes of SEZ activities in the labour market can partially confirm the hypothesis that capital inflow into SEZs decreases unemployment in the least developed regions (less-developed regions are statistically insignificant). Since relations between companies from and outside of SEZs in a given region are rather weak, it seems that an important improvement in the labour local market derives from the creation of new jobs by investors in SEZs. This phenomenon confirms an agglomeration process launched by SEZs, but concentrated only within zones and due to investments made by large companies based out of a different region.

\section{CONCLUSIONS}

This paper has examined the effect that SEZs have had on regional development in Poland across a broad range of metrics. We hypothesized that increased investment into SEZs should be correlated with higher gross value of fixed assets per company in the region (H1), more business entities (H2), and a reduction in the regional unemployment 
(H3). Our analysis showed that SEZs did indeed boost the overall economic and social development in Polish regions, but this relationship was contingent on poviat-specific factors. In particular, SEZs were associated with a higher increase in the gross value of fixed assets per company in comparison to regions without an SEZ, but only in the least- and lesser-developed poviats. However, the number of economic entities in regions with SEZs was statistically insignificant compared to those that had no SEZs, suggesting that the zone approach was not effective in improving a region's overall investment attractiveness. Finally, as regards the labour market, it appeared that SEZs were effective in lowering the unemployment rate in the most-lagging regions, an important point given that this was the main driver of the SEZ policy in Poland.

On balance, thus, it appears that SEZs had a mostly favourable impact on regional socio-economic indices in Poland, but these results were dependent upon both the development level of the targeted poviat and how committed the local authorities were to invest in the SEZ. Moreover, once we consider that unemployment rates fell even though the number of economic operators did not grow at an abnormal pace, it appears that SEZs encouraged an agglomeration process, producing new jobs but only in a select few (mainly large) companies.

Of course, these successes must be balanced against the possible inefficiencies of SEZs as a tool of regional development, including the fact that offering tax allowance and/or other financial and administrative preferences can disturb competition and distort local markets. Indeed, while such incentives may attract investors, our results in the Polish case show that the benefits accrued only to the SEZ itself and not to the greater region where the SEZ was established. Moreover, as economic zones are open to all entrepreneurs and companies originating from the same country or region (unlike export processing zones), the incentive to invest within the region of the SEZ was diluted; in 
reality, firms could run their economic activities within a zone but still invest outside of the SEZ, preferably in their home region. This was the case in Poland, as investors in zones continued to maintain contacts with suppliers and direct wholesalers established previously, providing no stimulation to the local market.

The policy ramifications of the Polish experience reinforce basic economic tenets, mainly that large marginal gains can accrue from investment in less-developed regions. For countries seeking to stimulate regional development, SEZs may provide some benefit if targeted to poorer regions, but even then, the SEZ must be properly structured in order to keep investment within the region and avoid leakage across the country (as in Poland). Additionally, in order to mitigate negative consequences for competition within the region, SEZs should be used in complement with other public interventions aimed at improving regional development, ensuring that SEZs encourage building new linkages rather than assisting market-based agglomeration process of companies. In this regard, further research is needed on optimal policies of assistance and the development of regions which hold SEZs.

\section{ACKNOWLEDGEMENT}

I wish to thank the referees from Regional Studies, as well as Professors John B. Parr, the University College London, Elżbieta Kawecka-Wyrzykowska, Warsaw School of Economics, for their helpful comments, constructive criticisms and suggestions, which have improved the paper overall. Thanks are also due to participants of the CASE Conference on Special Economic Zones in Warsaw, Poland, in April 2015, and special thanks to Dr Christopher A. Hartwell of CASE, Guest Editor of this special issue of Regional Studies, for the extremely valuable remarks and suggestions of changes, which 
substantially improved the paper. All remaining errors are solely attributable to the authors.

\section{References}

Act (1994) of 20 October 1994 on special economic zones (JL 1994, no 123, item. 600). Ambroziak, A. A. (2009). Krajowa pomoc regionalna w specjalnych strefach ekonomicznych $w$ Polsce [Regional state aid in special economic zones in Poland]. Warsaw: Warsaw School of Economics Press.

Ambroziak, A. A. (2015a). Theoretical Aspects of Regional Intervention [in:] AA Ambroziak (ed.) Regional Dimension of the EU Economic Policy in Poland, Warsaw School of Economics Press, Warsaw;

Ambroziak, A. A. (2015b). The effects of granting state aid in special economic zones after Poland's accession to the European Union. In G. Wojtkowska-Łodej \& H. Bąk (Eds.), Selected Aspects of the Functioning of Poland in the European Union. The Balance of Ten Years of Membership (pp. 245-266). Warsaw: Warsaw School of Economics Press.

Baker, J. L. (2000). Evaluating the Impact of Development Projects on Poverty. A Handbook for Practitioners, Washington: The World Bank.

Cieślik, A. (2005). Regional characteristics and the location of foreign firms within Poland. Applied Economics, 37(8), 863-874.

Domański, B., Gwosdz, K. (Eds.) (2005). Dziewięć lat doświadczeń pierwszej polskiej specjalnej strefy ekonomicznej, Mielec 1995-2005 [Ten years experience of the first Polish special economic zone, Mielec 1995-2005]. Kraków: Instytut Geografii i Gospodarki Przestrzennej Uniwersytetu Jagiellońskiego.

Dziemianowicz, W., (2008). Konkurencyjność gmin w kontekście relacji władze lokalne - inwestorzy zagraniczni [Competitiveness of local units in the context of relationship between a local authority and foreign investors], Wydawnictwa Uniwersytetu Warszawskiego, Warszawa.

Dziemianowicz, W., Hausner, J. \& Szlachta, J. (2000). Restrukturyzacja ośrodków monokulturowych na przykładzie Mielca [Restructuring of monoculture centres. Mielec case]. Warsaw: Instytut Badań nad Gospodarką Rynkową. 
Engman, M., Onodera O. \& Pinali, E. (2007). Export Processing Zones: Past and Future Role in Trade and Development. OECD Trade Policy Papers, No. 53, OECD Publishing.

Ernst and Young. (2011). Specjalne Strefy Ekonomiczne po 2020 r. [Special Economic Zones after 2020]. Warsaw.

European Commission. (1998). Guidelines on national regional aid, OJ C 74, 10.03.1998, p. 6.

European Commission. (2005) State Aid Action Plan. Less and better targeted state aid: a roadmap for state aid reform 2005-2009, COM(2005) 107 final, Brussels.

European Commission. (2006). Guidelines on national regional aid, OJ C 54, 4.03.2006, p. 13.

European Commission. (2014). Common methodology for State aid evaluation, SWD(2014)179, Brussels.

Fujita, M., Krugman, P. \& Venables, A.J. (1999). The Spatial Economy. Cities, Regions, and International Trade. Cambridge - London: MIT Press,.

Gertler, P., Martinez, S., Premand, P., Rawlings, L.B. \& Vermeersch, Ch.M.J. (2011) Impact Evaluation in Practice. World Bank.

Hajduga, P. (2014) Specjalne strefy ekonomiczne w Polsce a kształtowanie kapitału ludzkiego [Special Economic Zones in Poland and the Formation of Human Capital], Research Papers of Wroctaw University of Economics 367: 90-101. Heckman, J.J. \& Hotz V.J. (1989). Choosing Among Alternative Nonexperimental Method for Estimating the Impact of Social Programs: The Case of Manpower Training. Journal of the American Statistical Association, 84(408): 862-874.

Holland, P.W. (1986). Statistics and Causal Inference. Journal of the American Statistical Association 81(396), 945-960.

Kozaczka, M. (2007). Tarnobrzeska Specjalna Strefa Ekonomiczna Euro-Park Wisłosan [Tarnobrzeg Special Economic Zone Euro-Park Wisłosan]. Ekonomika i Organizacja Przedsiębiorstwa, 11, 35-43.

Kozaczka, M. (2008). Specjalne strefy ekonomiczne w Polsce 1995-2007 [Special Economic Zones in Poland, 1995-2007]. Stalowa Wola: Katolicki Uniwersytet Lubelski Jana Pawła II.

KPMG. (2012). Special Economic Zones, Edition 2012, Warsaw.

Krugman, P. (1990). Increasing Returns and Economic Geography. Cambridge: National Bureau of Economic Research. 
Krugman, P. (1991). Geography and Trade, Massachusetts: MIT Press.

Kryńska, E. (2000). Polskie Specjalne Strefy Ekonomiczne - zamierzenia i efekty [Polish Special Economic Zones - intentions and effects.]. Warsaw: Europejski Instytut Rozwoju Regionalnego i Lokalnego Uniwersytetu Warszawskiego.

Laskowski, P. (2013). Specjalne strefy ekonomiczne jako czynnik Rozwoju regionalnego na przykładzie wałbrzyskiej specjalnej strefy ekonomicznej “INVEST-PARK” [Special Economic Zones as a Factor of Regional Development Based on Wałbrzych Special Economic Zone "INVEST-PARK"]. Prace Naukowe Uniwersytetu Ekonomicznego we Wrocławiu, 307, 317-329.

Lizińska, W., Marks-Bielska, R. \& Kisiel, R. (2011). Atrakcyjność inwestycyjna gmin i znaczenie w jej kształtowaniu preferencji specjalnej strefy ekonomicznej [Investment attractiveness of municipalities and its importance in shaping the a special economic zone]. Rocznik Nauk Rolniczych, G98(3), 191-204.

Ministerstwo Gospodarki (2014) Informacja o realizacji ustawy o specjalnych strefach ekonomicznych. Stan na 31 grudnia 2013 r. [Information on the outcomes of the Act on Special Economic Zones, as of December 31, 2013], Warsaw.

Nazarczuk, J.M. (2013). Potencjał rozwojowy a aktywność inwestycyjna województw i podregionów Polski [Development potential and investment activity of voivodeships and subregions of Poland], Wydawnictwo Uniwersytetu Warmińsko-Mazurskiego, Olsztyn.

Pastusiak, R. (2011). Specjalne Strefy Ekonomiczne jako stymulator rozwoju gospodarczego [Special Economic Zones as a stymulator of economic development], Wydawnictwo Uniwersytetu Łódzkiego, Łódź.

PriceWaterhouseCoopers. (2008). Specjalne Strefy Ekonomiczne. 10 lat w Polsce [Special Economic Zones. 10 years in Poland]. Warsaw.

Rosenthal, S. S. \& Strange, W. C. (2001). The Determinants of Agglomeration. Journal of Urban Economics, 50(3), 191-229.

Ordinance (2008) of the Council of Ministers of 10 December 2008 r. on criteria of covering some land with a special economic zone, O.J. 224/1477, 2008.

Siudak, P. (2013). Negatywne efekty towarzyszące tworzeniu i funkcjonowaniu obszarów uprzywilejowanych na przykładzie polskich specjalnych stref ekonomicznych [The Negative Effects Accompanying the Creation and Functioning of Areas Economically Privileged as Exemplified by Polish Special 
Economic Zones]. Prace Naukowe Uniwersytetu Ekonomicznego we Wrocławiu, 321, 124-135.

Siudak, P. Wątorek. B. (2011). Specjalne strefy ekonomiczne w Polsce w latach 19952009. Państwowa Wyższa Szkoła Zawodowa im. Witelona w Legnicy, Legnica. Trzciński, R. (2009). Wykorzystanie technik propensity score matching w badaniach ewaluacyjnych, Warsaw: Polska Agencja Rozwoju Przedsiębiorczości.

Typa, M. (2013). Specjalne strefy ekonomiczne w Polsce jako stymulator konkurencyjności regionów. Kwartalnik Nauk o Przedsiębiorstwie, 27(2), 16-25.

Venables, A. J. (2006). Shifts in Economic Geography and Their Causes. Economic Review, 91(4), 61-85.

Weber A. (1929) Alfred Weber's Theory of the Location of Industries, The University of Chicago Press, Chicago-Illinois.

White, H. (2006). Impact Evaluation: The Experience of the Independent Evaluation Group of the World Bank. Washington: World Bank.

World Bank. (1992) Export Processing Zones, Policy and Research Series No.20, Washington: World Bank.

World Bank. (2008). Special Economic Zones, performance, lessons learned and implications for zone development. Washington: World Bank.

\footnotetext{
${ }^{\mathrm{i}}$ It should be noted that there were 380 national units of the territorial statistics NUTS 4 (poviats) in Poland from the beginning of 2012, however we excluded some of them due to the fact that: a) the city of Wałbrzych belonged to the wałbrzyski poviat until the end of 2012 and only in 2013 did it become a separate Wałbrzych poviat, thus in order to ensure the comparability of outcomes, we decided to add data concerning Wałbrzych to data on the wałbrzyski poviat in 2013, b) three poviats (the richest cities: Warsaw, Poznań and Kraków) represented three individual cases in three separate categories therefore no comparative analysis was feasible.

${ }^{\text {ii }}$ However, conclusions based on investment intensity should be viewed with caution due to a small number of poviats in certain subgroups of the 'less' and 'more' developed units, in contrast to the 'least' developed poviats
} 